\title{
AN EXAMINATION OF GENDER AND RACE DIFFERENCES IN YOUTH SMOKING RESPONSIVENESS TO PRICE AND TOBACCO CONTROL POLICIES
}

Frank J. Chaloupka

Rosalie Liccardo Pacula

Working Paper 6541 
NBER WORKING PAPER SERIES

\title{
AN EXAMINATION OF GENDER AND RACE DIFFERENCES IN YOUTH SMOKING RESPONSIVENESS TO PRICE AND TOBACCO CONTROL POLICIES
}

Frank J. Chaloupka

Rosalie Liccardo Pacula

Working Paper 6541

http://www.nber.org/papers/w6541

\author{
NATIONAL BUREAU OF ECONOMIC RESEARCH \\ 1050 Massachusetts Avenue \\ Cambridge, MA 02138 \\ April 1998
}

This research was supported by a grant from the Centers for Disease Control and Prevention and the Robert Wood Johnson Foundation. An earlier version of this paper was presented at the March 1998 annual meeting of the Society for Research on Nicotine and Tobacco in New Orleans. Any opinions expressed are those of the authors and not those of the National Bureau of Economic Research.

(C) 1998 by Frank J. Chaloupka and Rosalie Liccardo Pacula. All rights reserved. Short sections of text, not to exceed two paragraphs, may be quoted without explicit permission provided that full credit, including (C) notice, is given to the source. 
An Examination of Gender and Race Differences

in Youth Smoking Responsiveness to Price

and Tobacco Control Policies

Frank J. Chaloupka and Rosalie Liccardo Pacula

NBER Working Paper No. 6541

April 1998

\begin{abstract}
$\underline{\text { ABSTRACT }}$
Nationally representative studies consistently report significant gender and racial differences in youth smoking rates, although little research has been done to explain why. In this paper we examine one possible source for this variation: differences in youth responsiveness to changes in price or tobacco control policies. Using data from the 1992-1994 Monitoring the Future surveys, we find that young men are much more responsive to changes in the price of cigarettes than young women. The participation elasticity for men is almost twice as large as that for women. Further, we find that smoking rates of young black men are significantly more responsive to changes in price than young white men. In addition, we find significant differences in responsiveness to particular tobacco control policies. Smoking rates among white youths are responsive to anti-tobacco activities and clean indoor air restrictions, while smoking rates among black youths are significantly influenced by smoker protection laws and restrictions on youth access.
\end{abstract}

Frank J. Chaloupka

Department of Economics (M/C 144)

University of Illinois at Chicago

601 South Morgan St.

Chicago, IL 60607-7121

and NBER

fjc@uic.edu
Rosalie Liccardo Pacula

School of Business Administration

University of San Diego

5998 Alcala Park

San Diego, CA 92110-2492

and NBER

rpacula@acusd.edu 


\section{Introduction}

Nationally representative studies consistently report significant gender and racial differences in youth smoking rates. According to data presented in the 1994 Surgeon General Report, white youth are more than twice as likely to report smoking in the previous month than black youth. Although smoking rates among females were higher than males during the 1980s, this trend has reversed itself in the 1990s, with more young men reporting that they currently smoke than young women. ${ }^{1}$ Although the differences in smoking rates are well documented, little research has been done to help explain why these differences exist or whether they are persistent over time.

An examination of historical trends in smoking rates among a nationally representative sample of high school seniors reveal that the differences we see today in smoking rates have not persisted over time. Figure 1 shows thirty-day smoking prevalence among high school seniors by gender and race from 1975 to 1997 . Although smoking prevalence among all four groups declined from 1977 to 1980 , the smoking rates move in very different directions throughout the 1980s. Young black smokers continue to dramatically decrease their thirty-day prevalence throughout the 1980s. Similarly smoking rates among young women smokers fall throughout the 1980s, but the declines are not nearly as large as among black smokers. Smoking rates by men and whites, however, level off in the early 1980s and start to moderately climb throughout the 1980s. Interestingly, from 1991-1996 there is again a parallel movement in the smoking rates of these four groups, but now smoking rates among young men are higher than smoking rates among young women.

What caused these dramatic differences in youth smoking rates during the 1980s? One possible explanation is that there was a large change in a significant predictor of youth smoking 
during this time period that influenced these four groups differently. For example, between 1981 to 1990 the average real price of a twenty-pack of cigarettes rose from a twenty-five year low of $\$ 0.69$ to $\$ 1.10 .^{2}$ This represents a $63 \%$ increase in the real price of a pack of cigarettes.

Previous economic research shows that smoking by youth is sensitive to changes in the price of cigarettes. $^{3}$ It may be that this significant price increase influenced smoking rates of youths differently.

In this paper we examine differences in youth responsiveness to changes in price and specific tobacco control policies using a nationally representative sample of youths from the Monitoring the Future surveys. We find that significant differences do exist both by gender and by race. For example, men are much more responsive to changes in the price of cigarettes than women; the participation elasticity for men is almost twice as large as that for women. Further, we find that smoking rates of young black men are significantly more responsive to changes in price than young white men. We also find that there are significant differences in youths' responsiveness to tobacco control initiatives by race. Smoking rates among white youths are much more responsive than black youths to anti-tobacco activities and clean indoor air restrictions. Smoking rates among black youths, on the other hand, are significantly influenced by smoker protection laws and restrictions on youth access whereas smoking rates among white youths are not.

\section{Methods}

Data on youth smoking prevalence come from the 1992-1994 Monitoring the Future surveys of eighth, tenth, and twelfth grade students conducted by the Institute for Social Research (ISR) at the University of Michigan. Every year since 1975, ISR has collected data on tobacco, alcohol, and other drug use from a nationally representative sample of approximately 
17,000 high school seniors. In 1991, comparable surveys of eighth and tenth grade students were added. The survey is conducted in school and addresses youths' attitudes, perceptions and use of legal and illicit drugs. Given the sensitive nature of the subject matter, great care is taken to ensure reliable and valid responses. For example, parents are not informed of their child's responses.

From responses to these surveys it is possible to construct a dichotomous indicator of smoking participation that is set equal to one for youth reporting any cigarette consumption in the previous 30 days and zero otherwise. In addition, various other socioeconomic and demographic variables can be constructed from the general background data that are collected. Variables used in this analysis include: gender (male or female), race (white, Black and other race), age, average weekly income from all sources (employment, allowances and other), current grade (eighth, tenth or twelfth), marital status (married/engaged or single), parental education (less than high school graduate, high school graduate, more than high school graduate), family structure (live alone, only mother present, only father present, both parents present, live with other(s)), mother's work status while the youth was growing up (not employed, employed parttime, employed full-time), existence of siblings, average number of hours worked weekly, living in rural/urban area, and frequency of participation in religious services (no participation, infrequent participation and frequent participation).

Based on each youth's county of residence, measures of cigarette price and state and local tobacco control policies are added to the survey data. The cigarette price measure reflects the average state level price for a pack of 20 cigarettes and is taken from the Tobacco Institute's annual Tax Burden on Tobacco.${ }^{4}$ It is a weighted average of the prices of single packs, cartons, and vending machine sales and includes state level excise taxes and the price of generics. To 
capture potential cross-border shopping for cigarettes that, if excluded, may bias estimates of price towards zero, an additional variable representing the largest price difference between the youth's state of residence and states within 25 miles of the youth's county of residence is also included. This variable is set equal to zero for those youth that live in states with lower prices than nearby states and for youth living in counties more than 25 miles from another state.

Four variables capturing state and local tobacco policies are also merged into the data. The first is a dummy variable set equal to one in those states that earmark a portion of cigarette tax revenues for anti-tobacco activities and zero otherwise. Those states that set aside these funds are generally believed to be more aggressive in discouraging smoking. The second is another dummy variable set equal to one in those states that have some form of smoker protection legislation and equal to zero otherwise. States that have enacted smoker protection laws are generally believed to be less aggressive in their efforts to discourage smoking. The final two variables are indices of clean indoor air restrictions and youth access laws passed at the state and local level. The index of clean indoor air restrictions represents the sum of five independent variables capturing the fraction of the population in the youth's county of residence subject to state or local restrictions on smoking in private work sites, restaurants, retail stores, schools, and other public places. The index of youth access is constructed similarly by summing five different variables capturing different aspects of youth access. The first two variables included in this index are dummy variables set equal to one if the state has a minimum legal purchase age of at least 18 and if the states requires point-of-sale signage stating the minimum legal purchase age. Two other variables included in this index represent the fraction of the county population in the youth's county of residence that is subject to restrictions on vending machine sales and distribution of free samples. The last variable included in this index 
represents the fraction of the county population that is living in areas where tobacco licensing is required. The data on state level policies were taken from the Coalition on Smoking OR Health's (CSH) annual State Legislated Actions on Tobacco Issues. ${ }^{5}$ Similar information on county and city level restrictions was obtained from the National Cancer Institute's monograph summarizing major local control policies, updated with information from $\mathrm{CSH}^{6}$

Descriptive statistics of the variables of interest by gender and race are provided in Table One. As has been found in other surveys, smoking rates among black (8.0\%) are significantly lower than those of young whites $(25.6 \%)$ in our sample. There is not a significant difference in smoking prevalence by gender, however. Approximately $23 \%$ of both males and females report currently smoking. Only a few of the policy variables differ across the groups. On average, fewer black youth are found in states that pass smoker protection laws. Similarly, fewer black youths live in states with tougher restrictions on smoking in public places.

\section{Results}

Using as controls the variables described above, the probability of smoking in the previous thirty days is estimated for males, females, blacks, whites, black males and black females using separate probit maximum likelihood specifications. Each specification includes a measure of the price of cigarettes along with the border-purchase variable. However, since the tobacco control policies are highly correlated, only one policy variable could be included in the regression equation at a time. We therefore estimate each of the six gender/race specific specifications five separate times, once with just the price included and four times with price and a different tobacco control policy. Since most of the policy variables are measured at the state 
level, standard errors are corrected for correlation created by having multiple observations within a single state using the cluster option in STATA 5.0.

Tables Two (A-D) report the marginal effects obtained from each of these separate regressions for the key policy variables, and then Table Three summarizes the main findings. In Table Three, two dashes indicate that the marginal effect of the variable on the probability of smoking was negative while the plus sign indicates that the marginal effect of the variable was positive. The average price elasticity resulting from the five different policy specifications of the models is reported in the final column. Although earmarking of state cigarette tax revenue to promote anti-tobacco activities has a negative and significant effect on smoking prevalence for young men and women, it is only smoking by white youth that are affected by this policy. State earmarking had no significant effect in any of the model specifications run separately for blacks. Smoker protection laws, on the other hand, have the largest positive effect on smoking rates by young blacks, and in particular black males. Smoking prevalence of white youth, male and female, is not affected by the existence of smoker protection laws. Clean indoor air laws significantly decrease smoking prevalence among young white males, but has no significant effect on any of the other groups of adolescents. Stricter youth access laws, on the other hand, significantly decrease smoking rates among young black males and females but have no significant effect on the smoking prevalence of white youth.

Economists use the price elasticity of demand as a way of measuring the responsiveness of consumption of a good to changes in the price of that good. It is measured as the percent change in the quantity of the good consumed, or in this case the percent change in the probability of smoking cigarettes, given a one percent change in the good's price, or $\eta_{d}=\% \Delta \mathrm{Q} / \% \Delta \mathrm{P}$. When a change in the probability of using a good is examined instead of the actual quantity 
consumed, we refer to this as a participation elasticity. A value greater than one in absolute value indicates that the change in the probability of smoking is greater in percentage terms than the change in the price of the good, and we say that consumption is very responsive to changes in price. A value less than one in absolute terms would indicate that the change in the probability of smoking was smaller in percentage terms than the change in price, meaning that consumption is not very responsive to price. Looking at the average price elasticities reported in the final column of Table Two we see that smoking participation among young men is much more sensitive to changes in price than smoking rates by young women, regardless of race. Smoking by young black men is the most price sensitive; a ten percent increase in the price of cigarettes will result in a $16.5 \%$ decrease in smoking prevalence among young black men, holding everything else constant. The same price increase would only result in a reduction in smoking participation of $8.6 \%$ among young white men. Smoking participation rates among women are the least responsive, although it is still significant for at least white young women. In most of the models run, the price of cigarettes had no significant effect on the probability of smoking for young black females.

\section{Discussion}

It should be kept in mind when interpreting these findings that most of the tobacco control policies included in this analysis only measure the existence of a policy and not its actual enforcement. There is considerable evidence in the recent literature suggesting that it is the enforcement of these policies and not the policies themselves that change behavior. ${ }^{3,7-8}$ Nonetheless, when the youth population is broken into these subgroups by race and gender it is interesting to see that many of the policies become significant for particular groups of young 
smokers. The most consistently significant policy variable is the price of cigarettes, which has a negative and significant effect on smoking prevalence for all the groups except young black women. This perhaps explains why it is the only variable that is consistently found to have a significant effect on youth smoking rates in general.

To what extent do the observed differences in price sensitivity explain the divergence in smoking trends that occurred in the 1980s? Assuming that youth smoking participation elasticities are fairly constant over time, it is possible to use the elasticities reported in Table Three to predict the change in smoking participation rates expected given the $63 \%$ increase in price that occurred from 1981 to 1990 . In Table Four, we record the actual and predicted change in smoking participation for the four basic subgroups represented in Figure 1. It is clear given the difference in predicted and actual values that the change in price alone does not adequately explain the actual patterns of consumption for all of the subgroups. Given the elasticities calculated in Table Three and the enormous change in price during the 1980 s, we would have expected to see smoking rates among all four groups decline, with smoking among black youths falling the most and smoking rates among females falling the least. Although smoking rates among blacks did experience the largest decline during the 1980s, the decline was not nearly as large as our model predicts. The same is true for females. Smoking rates among males and whites actually rose during the period, however, contrary to what our model predicts.

The poor performance of our model at explaining the shifts in smoking rates during the 1980s is not that surprising since it assumes that everything else that may influence youth smoking is held constant throughout the period. This was certainly not the case. For example, at the same time that the tobacco industry started raising the price of cigarettes, it dramatically increased its spending on advertising and promotions. Between 1981 and 1990 total advertising 
and promotional expenditures for the industry nearly tripled. ${ }^{1}$ This increase in advertising and promotion is not accounted for in our analysis and may be offsetting the effect of price on smoking rates. To the extent that advertising and promotional activities target specific youths more than others, this increase in expenditure is likely to influence youth smoking rates differently as well. There may be other missing determinants as well.

Even with these shortcomings, it is clear from this analysis that youths respond differently to changes in price and public policies. Significant differences exist by gender and race which suggests that public health professionals and policy makers keep in mind who their target user is when determining policy. There is clearly not a "one-size fits all" strategy for discouraging youth smoking. 


\section{References}

1. U.S. Department of Health and Human Services. Preventing tobacco use among young people: A report of the Surgeon General. Atlanta: U.S. Department of Health and Human Services, Public Health Service, Centers for Disease Control and Prevention, National Center for Chronic Disease Prevention and Health Promotion, Office of Smoking and Health, 1994.

2. Tobacco Institute, The Tax Burden on Tobacco, Washington, D.C.: Tobacco Institute, 1997.

3. Chaloupka FJ, Grossman M. Price, tobacco control policies, and youth smoking. National Bureau of Economic Research Working Paper Number 57401996.

4. Tobacco Institute, The Tax Burden on Tobacco, Washington, D.C.: Tobacco Institute, 1995.

5. Coalition on Smoking OR Health. State legislated Actions on Tobacco Issues. Washington, D.C.: Coalition on Smoking OR Health, various years.

6. National Cancer Institute, Major Local Tobacco Control Ordinances in the United States, Monograph 3, Bethesda, Maryland: U.S. Department of Health and Human Services, Public Health Service, National Institutes of Health, 1993.

7. Jason LA, Ji PA, Anes MD, Birkhead SH. Active enforcement of cigarette control laws in the prevention of cigarette sales to minors. JAMA 1991; 266: 3159-3161.

8. Wasserman J, Manning WG, Newhouse JP, Winkler JD. The effects of excise taxes and regulations on cigarette smoking. J Health Econ 1991; 10: 43-64. 
Figure 1

Thirty Day Smoking Prevalence Among High School Seniors

Monitoring the Future Historical Data (1975-1997)

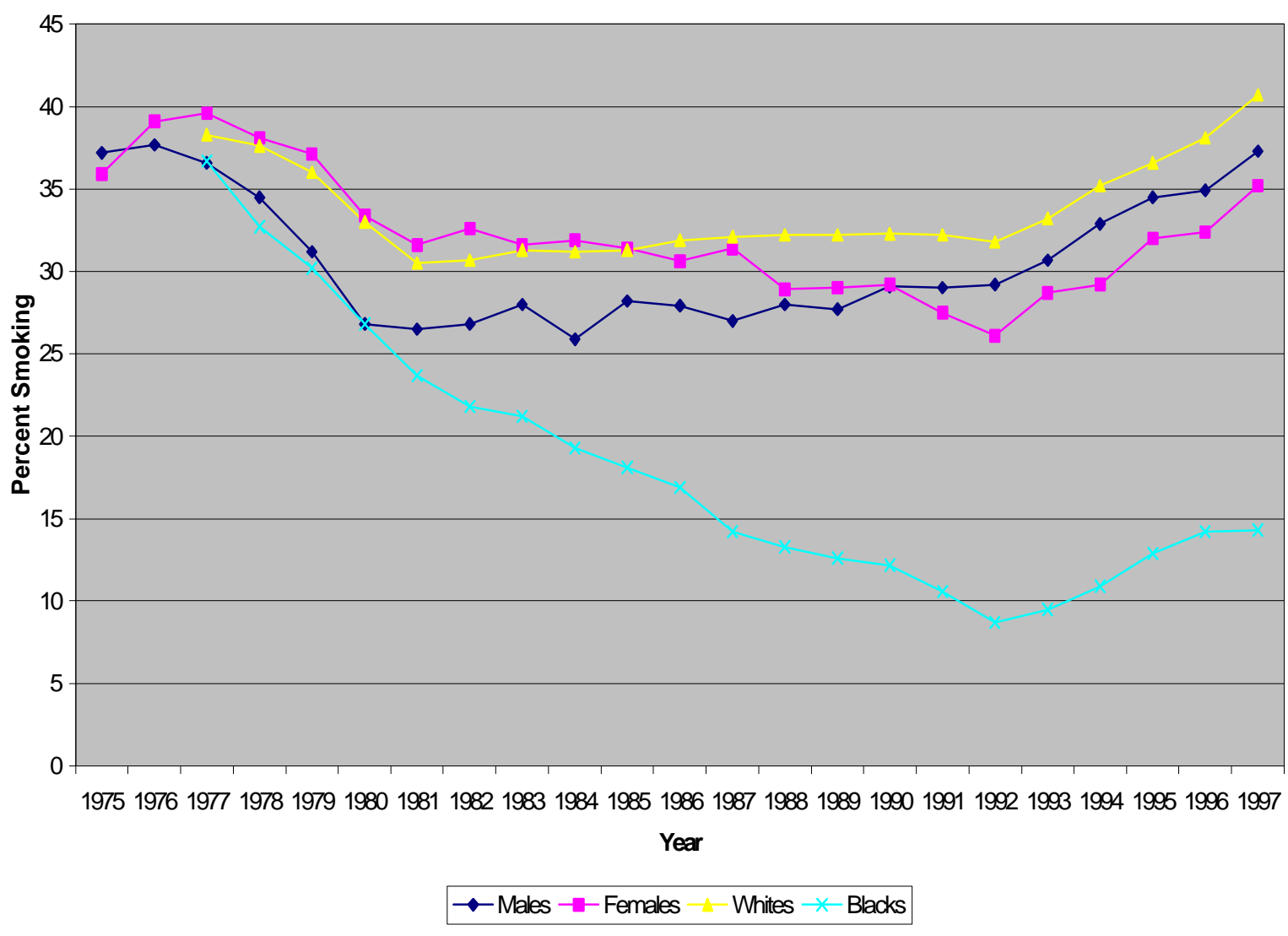


Table One

Descriptive Statistics by Gender and Race

Monitoring the Future 1992-1994

\begin{tabular}{|c|c|c|c|c|}
\hline & $\begin{array}{l}\text { Males } \\
53,209\end{array}$ & $\begin{array}{c}\text { Females } \\
\mathbf{5 7 , 5 0 8}\end{array}$ & $\begin{array}{l}\text { Whites } \\
74,745\end{array}$ & $\begin{array}{l}\text { Blacks } \\
12,897\end{array}$ \\
\hline Currently Smoking & $\begin{array}{c}.231 \\
(.422)\end{array}$ & $\begin{array}{c}.227 \\
(.419) \\
\end{array}$ & $\begin{array}{c}.256 \\
(.436) \\
\end{array}$ & $\begin{array}{c}.080 \\
(.271) \\
\end{array}$ \\
\hline $\begin{array}{l}\text { Average real price of } \\
\text { cigarettes }\end{array}$ & $\begin{array}{c}124.72 \\
(13.730)\end{array}$ & $\begin{array}{c}124.79 \\
(13.408)\end{array}$ & $\begin{array}{c}123.84 \\
(13.529)\end{array}$ & $\begin{array}{c}122.92 \\
(13.422)\end{array}$ \\
\hline $\begin{array}{l}\text { State earmarks tax } \\
\text { revenue }\end{array}$ & $\begin{array}{l}.157 \\
(.364)\end{array}$ & $\begin{array}{l}.160 \\
(.367)\end{array}$ & $\begin{array}{l}.129 \\
(.335)\end{array}$ & $\begin{array}{l}.104 \\
(.306)\end{array}$ \\
\hline $\begin{array}{l}\text { State smoker protection } \\
\text { laws }\end{array}$ & $\begin{array}{l}.485 \\
(.500)\end{array}$ & $\begin{array}{l}.467 \\
(.499)\end{array}$ & $\begin{array}{l}.512 \\
(.500)\end{array}$ & $\begin{array}{l}.398 \\
(.490)\end{array}$ \\
\hline $\begin{array}{l}\text { Index of Clean Indoor Air } \\
\text { Laws }\end{array}$ & $\begin{array}{c}3.751 \\
(1.451)\end{array}$ & $\begin{array}{c}3.757 \\
(1.434)\end{array}$ & $\begin{array}{c}3.721 \\
(1.453)\end{array}$ & $\begin{array}{c}3.324 \\
(1.660)\end{array}$ \\
\hline Index of Youth Access & $\begin{array}{l}3.985 \\
(.979)\end{array}$ & $\begin{array}{l}3.960 \\
(.981)\end{array}$ & $\begin{array}{l}3.949 \\
(.987)\end{array}$ & $\begin{array}{l}3.955 \\
(.990)\end{array}$ \\
\hline
\end{tabular}




\section{Table Two (A) \\ Single Policy Models - Gender Differences \\ Predicted Change in the Probability of Smoking}

\begin{tabular}{|c|c|c|c|c|}
\hline & \multicolumn{2}{|c|}{$\begin{array}{l}\text { Men } \\
(\mathbf{P}=.2312)\end{array}$} & \multicolumn{2}{|c|}{$\begin{array}{r}\text { Women } \\
(\mathbf{P}=.2267)\end{array}$} \\
\hline & Policy & Price & Policy & Price \\
\hline Price of Cigarettes & & $\begin{array}{l}-.0019 \\
(-5.43)\end{array}$ & & $\begin{array}{l}-.0012 \\
(-2.50)\end{array}$ \\
\hline Earmarking of taxes & $\begin{array}{l}-.0206 \\
(-2.50)\end{array}$ & $\begin{array}{l}-.0017 \\
(-5.94)\end{array}$ & $\begin{array}{l}-.0356 \\
(-2.45)\end{array}$ & $\begin{array}{l}-.0008 \\
(-2.56)\end{array}$ \\
\hline Smoker protection laws & $\begin{array}{l}-.0037 \\
(-0.40)\end{array}$ & $\begin{array}{l}-.0019 \\
(-5.68)\end{array}$ & $\begin{array}{l}.0016 \\
(0.16)\end{array}$ & $\begin{array}{l}-.0011 \\
(-2.49)\end{array}$ \\
\hline Clean indoor air index & $\begin{array}{l}-.0078 \\
(-3.37)\end{array}$ & $\begin{array}{l}-.0013 \\
(-3.40)\end{array}$ & $\begin{array}{l}-.0014 \\
(-0.52)\end{array}$ & $\begin{array}{l}-.0011 \\
(-2.14)\end{array}$ \\
\hline Youth access index & $\begin{array}{l}-.0030 \\
(-0.65)\end{array}$ & $\begin{array}{l}-.0018 \\
(-4.93)\end{array}$ & $\begin{array}{l}.000034 \\
(0.01)\end{array}$ & $\begin{array}{l}-.0012 \\
(-2.70)\end{array}$ \\
\hline \begin{tabular}{|l} 
Average price \\
Elasticity
\end{tabular} & & .928 & & .595 \\
\hline
\end{tabular}

Notes: z-scores are in parentheses. Each row represents a different specification which, in addition to price and the tobacco related policy noted in the row, includes an intercept, indicators of race, age, religiosity, rural residence, family structure, parental education, maternal work status, grade, year, average hours worked and real income. Standard errors were adjusted for clustering at the state level.

Table Two (B)

Single Policy Models- Race Differences Predicted Change in the Probability of Smoking

\begin{tabular}{|c|c|c|c|c|}
\hline & \multicolumn{2}{|c|}{$\begin{array}{l}\text { African-America } \\
(\mathbf{P}=. \mathbf{0 7 9 9})\end{array}$} & \multicolumn{2}{|c|}{$\begin{array}{l}\text { White } \\
(\mathrm{P}=.2557)\end{array}$} \\
\hline & Policy & Price & Policy & Price \\
\hline Price of Cigarettes & & $\begin{array}{l}-.0008 \\
(-1.77)\end{array}$ & & $\begin{array}{l}.0014 \\
(-4.37)\end{array}$ \\
\hline Earmarking of taxes & $\begin{array}{l}.0047 \\
(0.32)\end{array}$ & $\begin{array}{l}-.0008 \\
(-1.61)\end{array}$ & $\begin{array}{l}-.0259 \\
(-2.02)\end{array}$ & $\begin{array}{l}-.0012 \\
(-4.78)\end{array}$ \\
\hline Smoker protection laws & $\begin{array}{l}.0146 \\
(1.80)\end{array}$ & $\begin{array}{l}-.0007 \\
(-2.01)\end{array}$ & $\begin{array}{l}-.0091 \\
(-1.03)\end{array}$ & $\begin{array}{l}-.0015 \\
(-4.27)\end{array}$ \\
\hline Clean indoor air index & $\begin{array}{l}-.0013 \\
(-0.39)\end{array}$ & $\begin{array}{l}-.0007 \\
(-1.45)\end{array}$ & $\begin{array}{l}-.0043 \\
(-1.79)\end{array}$ & $\begin{array}{l}-.0011 \\
(-3.02)\end{array}$ \\
\hline & $\begin{array}{l}-.0066 \\
(-1.70)\end{array}$ & $\begin{array}{l}-.0006 \\
(-1.57)\end{array}$ & $\begin{array}{l}.0014 \\
(0.33)\end{array}$ & $\begin{array}{l}-.0014 \\
(-4.20)\end{array}$ \\
\hline $\begin{array}{l}\text { Average price } \\
\text { Elasticity }\end{array}$ & & 1.108 & & .639 \\
\hline
\end{tabular}

Notes: See Table Two (a). 
Table Two (C)

Single Policy Models - Men Only

Predicted Change in the Probability of Smoking

\begin{tabular}{|l|c|c|c|c|}
\multicolumn{2}{c}{$\begin{array}{c}\text { African-American } \\
\text { (P=.0911) }\end{array}$} & $\begin{array}{c}\text { White } \\
(\mathbf{P}=.2530)\end{array}$ \\
\hline & Policy & Price & Policy & Price \\
\hline Price of Cigarettes & & -.0013 & & -.0019 \\
& & $(-2.82)$ & & $(-5.45)$ \\
Earmarking of taxes & .0146 & -.0014 & -.0199 & -.0017 \\
Smoker protection laws & $(0.86)$ & $(-2.56)$ & $(-1.57)$ & $(-5.52)$ \\
& .0194 & -.0011 & -.0098 & -.0020 \\
Clean indoor air index & $(1.95)$ & $(-3.28)$ & $(-0.98)$ & $(-5.53)$ \\
& -.0010 & -.0012 & -.0087 & -.0013 \\
Youth access index & $(-0.28)$ & $(-2.05)$ & $(-2.94)$ & $(-3.09)$ \\
& -.0075 & -.0011 & .0012 & -.0019 \\
Average price & $(-1.39)$ & $(-2.54)$ & $(0.24)$ & $(-4.78)$ \\
elasticity & & 1.646 & & .861 \\
\hline
\end{tabular}

Notes: See Table Two (a).

Table Two (D)

Single Policy Models - Women Only

Predicted Change in the Probability of Smoking

\begin{tabular}{|c|c|c|c|c|}
\hline & \multicolumn{2}{|c|}{$\begin{array}{l}\text { African-American } \\
(P=.0706)\end{array}$} & \multicolumn{2}{|c|}{$\begin{array}{c}\text { White } \\
(P=.2584)\end{array}$} \\
\hline & Policy & Price & Policy & Price \\
\hline Price of Cigarettes & & $\begin{array}{l}-.0003 \\
(-0.70)\end{array}$ & & $\begin{array}{l}-.0010 \\
(-2.41)\end{array}$ \\
\hline Earmarking of taxes & $\begin{array}{l}-.0024 \\
(-0.17)\end{array}$ & $\begin{array}{l}-.0003 \\
(-2.56)\end{array}$ & $\begin{array}{l}-.0317 \\
(-2.03)\end{array}$ & $\begin{array}{l}-.0007 \\
(-2.25)\end{array}$ \\
\hline Smoker protection laws & $\begin{array}{l}.0104 \\
(1.21)\end{array}$ & $\begin{array}{l}-.0003 \\
(-0.64)\end{array}$ & $\begin{array}{l}-.0081 \\
(-0.81)\end{array}$ & $\begin{array}{l}-.0010 \\
(-2.33)\end{array}$ \\
\hline Clean indoor air index & $\begin{array}{l}-.0015 \\
(-0.39)\end{array}$ & $\begin{array}{l}-.0002 \\
(-0.52)\end{array}$ & $\begin{array}{l}.0001 \\
(0.04)\end{array}$ & $\begin{array}{l}-.0010 \\
(-2.12)\end{array}$ \\
\hline Youth access index & $\begin{array}{l}-.0054 \\
(-1.48)\end{array}$ & $\begin{array}{l}-.0002 \\
(-0.50)\end{array}$ & $\begin{array}{l}-.0001 \\
(-0.35)\end{array}$ & $\begin{array}{l}-.0010 \\
(-2.41)\end{array}$ \\
\hline $\begin{array}{l}\text { Average price } \\
\text { elasticity }\end{array}$ & & .4528 & & .4507 \\
\hline
\end{tabular}

Notes: See Table Two (a). 
Table Three

Summary of Findings by Race and Gender

\begin{tabular}{|c|c|c|c|c|c|}
\hline $\begin{array}{l}\text { Demographic } \\
\text { Group }\end{array}$ & $\begin{array}{l}\text { Earmarking } \\
\text { of tax } \\
\text { revenue }\end{array}$ & $\begin{array}{l}\text { Smoker } \\
\text { Protection } \\
\text { Laws }\end{array}$ & $\begin{array}{l}\text { Clean } \\
\text { Indoor } \\
\text { Air Laws }\end{array}$ & $\begin{array}{l}\text { Youth } \\
\text { Access } \\
\text { Laws }\end{array}$ & $\begin{array}{l}\text { Ave Price } \\
\text { Elasticity } \\
\text { (across all } \\
\text { models) }\end{array}$ \\
\hline Men & -- & - & $--^{*}$ & -- & $-0.928^{* * * *}$ \\
\hline White Men & $--^{\mathrm{a}}$ & -- & $--^{* * *}$ & + & $-0.861^{* * *}$ \\
\hline Black Men & + & $+^{* *}$ & -- & $--^{a}$ & $-1.646^{* * *}$ \\
\hline Women & -- $^{* *}$ & + & -- & + & $-0.595^{* *}$ \\
\hline White Women & $-{ }^{* *}$ & -- & + & -- & $-0.451^{* *}$ \\
\hline Black Women & -- & + & -- & $--^{a}$ & -0.453 \\
\hline Whites & $--^{* * *}$ & -- & $--^{*}$ & + & $-0.639^{* * *}$ \\
\hline White Men & $--^{a}$ & -- & $--^{* * *}$ & + & $-0.861^{* * *}$ \\
\hline White Women & $-{ }^{* *}$ & -- & + & -- & $-0.451^{* *}$ \\
\hline African Americans & + & $+{ }^{*}$ & -- & $--*$ & $-1.108^{*}$ \\
\hline Black Men & + & $+^{* *}$ & -- & $--^{a}$ & $-1.646^{* * *}$ \\
\hline Black Women & -- & + & -- & $--^{a}$ & -0.453 \\
\hline
\end{tabular}

Notes: All probit regressions included controls for age, average weekly income, current grade, marital status, parental education, family structure, mother's work status while the youth was growing up, existence of siblings, average number of hours worked weekly, living in rural area, and frequency of participation in religious services in addition to race and gender when appropriate. Significance of the variable is denoted as follows: $* * *$ denotes significance at the $1 \%$ level (two-tailed test), $* *$ denotes significance at the 5\% level (two-tailed test), $*$ denotes significance at the $10 \%$ level (two-tailed test), ${ }^{\text {a }}$ denotes significance at the $10 \%$ level (one-tailed test)

\begin{tabular}{lll} 
Change in Consumption Associated with Price Increases \\
& From 1981-1990 & \\
& Actual & Predicted \\
& Change in Smoking & Change in Smoking \\
& Rates & Rates \\
\hline graphic Group & $9.8 \%$ & $-58.4 \%$ \\
ine by males: & $-7.6 \%$ & $-37.4 \%$ \\
ine by females: & $5.9 \%$ & $-40.2 \%$ \\
ne by whites: & $-48.5 \%$ & $-69.7 \%$ \\
\hline ne by blacks: & &
\end{tabular}

